\title{
Homeowner Interactions with Residential Trees in Urban Areas
}

\author{
Jana Dilley and Kathleen L. Wolf
}

\begin{abstract}
Urban forests are a critical element in sustainable urban areas because of the many environmental, economic, and social benefits that city trees provide. In order to increase canopy cover in urban areas, residential homeowners, who collectively own the majority of the land in most cities, need to engage in planting and retaining trees on their properties. This collaborative research project surveyed homeowners in Seattle, Washington, U.S., to examine their behaviors and attitudes toward the trees on their property. Attitudes toward trees were mapped to examine geographic distribution, as Seattle has a legacy of neighborhood-based planning. Results show that homeowners planted trees during non-optimal times of the year, preferred trees that are small at maturity over trees that are large at maturity, and showed increased interest in fruit trees. Homeowners intend to plant fewer trees in the future than they have in the past. This research is a model for social science efforts that can be used to develop targeted public outreach programs at the neighborhood scale to increase the planting and retention of trees on residential property.

Key Words. Benefits; Canopy Cover; Fruit Trees; Homeowner; Human Dimensions; Neighborhood Planning; Private Property; Residential Trees; Seattle; Social Science; Tree Planting; Washington.
\end{abstract}

Urban forestry has been described as the planting, cultivation, and management of trees for their present and potential future contribution to the physiological, sociological, and economic well-being of urban communities (Jorgensen 1974). A sustainable urban forest is one that maintains "healthy and functional vegetation and associated systems that provide long-term benefits desired by the community" (Dwyer et al. 2003). Tree cover contributes to broader sustainability goals of local government agencies in providing environmental, social, health, and economic benefits to urban residents. For instance, research indicates that trees contribute to heat island reduction, efforts to address climate change, and lower levels of stormwater runoff (Rosenfeld et al. 1995; Xiao et al. 1998; McPherson et al. 2002). Recent research indicates associations of trees with health benefits of reduced cardiovascular disease (Donovan et al. 2013), less risk of poor infant birth outcomes (Donovan et. al. 2011), and reduced crime rates (Donovan and Prestemon 2012). Attaining sustainable urban forests requires combined attention to the condition of the natural resource and appropriate management of that resource, as well as recognition of the human dimensions or the impact of people on urban forests.

Stormwater management has become an important driver for urban forestry efforts by municipalities in recent years. In 2013, the mayor of Seattle, Washington, U.S., signed an Executive Order directing the management of 700 million gallons of stormwater runoff by 2025 using green infrastructure, and included urban forest canopy as a strategy (City of Seattle 2013). The City of Pittsburgh's Urban Forest Management Plan (Pittsburgh, Pennsylvania, U.S.) similarly calls out the importance of urban forests for stormwater management, and offers recommendations such as targeted planting sites and the use of large trees where possible to maximize benefits (Davey Resource Group 2012).
Tree canopy cover can serve as one indicator of the extent to which trees and forests are providing critical services to local residents (Nowak et al. 2010). To conserve and enhance all tree-related benefits, municipal governments across the United States have set targets for increased canopy cover. The City of Seattle has set a goal to reach $30 \%$ canopy cover by 2037, an increase from the $23 \%$ cover estimated as of 2007 (City of Seattle 2007; Parlin 2009). Single-family residential property constitutes $56 \%$ of Seattle's land base, and the City's urban forest managers estimate that two-thirds of the approximately 300,000 net new trees necessary to meet Seattle's canopy goal need to be planted on single-family residential property.

Many different programs and strategies can be implemented to achieve a city's tree-planting policy and goals, such as street tree planting campaigns and restoration of public lands. Recognition of the importance of the homeowner population in meeting the City of Seattle's goals led to a collaborative research project, between the City and the University of Washington, to examine residents' attitudes and behaviors toward planting and maintaining trees on private residential property. Results of the survey research have contributed to substantial revision of tree planting programs aimed at the neighborhood scale. This paper discusses the importance of working with urban homeowners, presents results of the Residential Trees Survey of homeowners in Seattle, and discusses how the survey results apply to urban forest management.

\section{LITERATURE AND BACKGROUND}

To be effective, local government planning and management of urban forests must acknowledge a wide variety of landscape situations and stakeholders. An early model of urban forest sustain- 
ability (Clark et al. 1997) continues to be used as the basis for strategic urban forest planning and management (Kenney et al. 2011) and is organized into three components: vegetation, resource management, and community frameworks. Clark's model acknowledged the importance of human dimensions in urban forestry, as the future of any city's urban forest is intertwined with the actions and support of human populations. Other researchers have also highlighted the importance of working within the social context of a city in order to achieve natural resources objectives (Dwyer 2003; Wolf and Kruger 2010; Wolf et al. 2013).

\section{Human Dimensions and Urban Forestry}

The term human dimensions refers to how and why humans value natural resources, how humans want resources managed, and how humans affect or are affected by natural resource management decisions. The concept incorporates a variety of ideas and practices, including cultural, social, and economic values; individual and social behavior; psychological responses, such as preferences and perceptions; socio-demographic variability; legal and institutional frameworks of management; communication and education; and decision-making processes of management (Decker et al. 2001). Human dimension inquiries strive to understand some aspect(s) of these social dynamics and how to integrate that understanding into management planning and actions.

Resource managers and decision makers typically address natural systems yet often encounter the human dimensions of complex and competing values, perceptions, and actions at multiple jurisdictional and societal scales (Pickett et al. 2011). The heterogeneity and complexity of natural systems in cities (Cadenasso 2007; Pickett and Cadenasso 2009) is due to the influences of ecological fragmentation, soils and hydrology disturbance, patchy biodiversity, and microclimate effects. Society, with its multiple jurisdictions, stakeholders, values, interests, institutions, capacities, and vulnerabilities, is similarly diverse and complex (Flint et al. 2009). Specific social challenges for urban forest planning and management include fragmentation of urban forest ownership, inadequate public support of funding, and a lack of knowledge about landscape objectives of urban landowners (Dwyer 2003).

Human dimensions can be expressed (and studied) at different scales, from individuals, to neighborhoods, to cities, and increasing in scope to include entire nations or continents. Increases in canopy cover, and the concurrent increases in benefits provided by urban forests, are dependent on the activities of both private and public property owners across city parcels, large and small. However, residents on single-family parcels may have the largest impact on urban forests because single-family properties currently make up the majority of the land base in most large cities in the United States. The average U.S. city is $40 \%$ residential land, $24 \%$ vacant and wildland, $13 \%$ commercial and industrial areas, $12 \%$ other (such as agriculture, orchards, and transportation), $6 \%$ institutional, and $5 \%$ parks (Dwyer et al. 2000). Individual residential parcels tend to be small; the tree planting and care activities of a single household may have little impact on the overall urban forest. Yet collectively, single-family homeowners can make major contributions to increasing overall canopy cover. Urban forest managers who wish to increase canopy cover must include policies and programs that encourage residents to plant, retain, and maintain trees on their properties.

\section{Homeowner Response to Street and Yard Trees}

Interactions between resource managers and local stakeholders are needed to facilitate the identification of management priorities (Flint et al. 2009). What do researchers currently know about the human dimensions of homeowners and urban trees? General public attitudes about trees are a starting point. A national survey found that Americans ranked shade and cooling benefits as the most important reasons to have urban trees, and allergies and blocked views of business signs as the most significant problems (Lohr et al. 2004). Attitudes can also be sampled on a statewide level. Zhang et al. (2007) tested for demographic traits and support for urban forestry programs in Alabama, finding that factors associated with greater willingness to donate money or time to urban forestry efforts included awareness of forestry-related programs, full-time employment, being of middle age or younger (less than 56 years old), and having an annual income greater than USD $\$ 75,000$.

More research efforts have addressed residents' perceptions of street trees, such as visual comparisons of different species (Sommer et al. 1989) and response to species, form, size, and diversity (Schroeder and Ruffolo 1996). The single largest factor determining the attractiveness of street scenes was the size of trees, with residents reporting that streets were especially attractive when larger trees canopied the street (Schroeder and Ruffolo 1996), a sentiment shared by residents facing tree loss due to emerald ash borer (Heimlich et al. 2008). Perceptions of overall satisfaction with street trees are associated with greater appreciation of benefits over annoyances (Sommer and Sommer 1989; Sommer et al. 1990). A cross-cultural comparison between U.S. and UK residents found that overall opinions about visual character and benefits of nearby street trees did not differ much between nations (Schroeder et al. 2006). Results are consistent with a study in southwest England where residents had a good overall opinion of nearby street trees, rating visual attractiveness as the highest benefit, yet indicating a preference for smaller trees (Flannigan 2005).

Tree surveys usually report stated preferences (what people claim to prefer or do). Revealed preferences (or actual behaviors) can be derived from economic exchange or purchases. Such studies reveal that people don't simply claim to want trees, but act on their preferences by spending money on homes with existing trees. Tree cover in and around housing parcels (up to 40\%-60\%) had a positive effect on average home sale price in two Midwest U.S. counties (Sander et al. 2010), findings that are consistent with other hedonic studies of trees and market values (as summarized in Donovan and Butry 2010). In Portland, Oregon, U.S., trees had positive effects on home sales price and time on market, as well as rental prices of single-family homes (Donovan and Butry 2010).

Of interest in this study were residents' attitudes and behaviors concerning all trees associated with their property, both yard and street trees, as residential tree planting behavior across an entire parcel is important to reach canopy cover goals. Homeowners' commitment to care for street trees has been studied. Surveyed residents having a street tree in front of their home were more likely to think that such trees were important than were residents without a street tree; of those having nearby street trees, $37 \%$ either cared for the tree themselves or paid someone else to care for the tree (Gorman 2004). Concerning homeowner tree planting, Summit and McPherson (1998) found that $68 \%$ of the surveyed residents 
in Sacramento, California, U.S., planted a tree on their property and were most likely to do so shortly after moving into a new home. Sixty-six percent had removed at least one tree; the most common reason for removal was that the tree was dead, followed by root and size problems, and finally by messiness and tendency of the trees to draw insects. Overall, the rate of tree planting was higher than tree removal. The same study found shade and aesthetics to be the main reasons residents chose to plant trees; energy savings, environmental benefits, privacy, and property values were of lesser importance.

\section{Seattle's Neighborhood Planning Traditions}

Examining human dimension patterns at the neighborhood level provides another scale of understanding. Planners and other public officials have come to see the neighborhood as an important geographic and social unit for organizing planning efforts (Silver 1985; Chaskin 1998; Rohe 2009). Residents are most familiar and concerned with their neighborhoods, for what happens in neighborhoods affects quality of life and (for many) economic conditions (Logan and Molotch 1987). Neighborhood planning objectives start with achieving good physical design and providing basic infrastructure, but usually include broader social objectives, such as creating healthy social communities, empowering neighborhood residents, developing neighborhood economies, and preserving environmental quality (Sirianni 2007; Rohe 2009).

The City of Seattle has a long tradition of neighborhoodbased planning. In the mid-1990s, Seattle developed an especially ambitious and successful policy for collaborative processes in comprehensive planning (Sirianni 2007). In combined top-down, bottom-up initiatives, neighborhood groups were empowered to develop their own plans deliberatively, but with clear procedures for accountability to the city. The city council and departments then aligned the plans to set targets for policy and programs, such as sustainable development, housing, transportation, and funding bonds and levies. There are thirteen independent District Councils that convene representatives from community councils, nonprofit organizations, and business districts. The districts deliver findings and recommendations to the City. The city's departments and agencies, in turn, often develop and deliver programs that are geographically and politically aligned with the districts and are administered by the Seattle Department of Neighborhoods (2012). Such programs include, but are not limited to, community gardens, neighborhood grants, community engagement, and historic preservation.

\section{Neighborhood Scale Responses to the Urban Forest}

Some of the most recent research about urban natural resources focuses on the explicit integration of social and ecological systems (Pickett et al. 2011). The Baltimore Ecosystem Study is a broad program of research that is yielding new knowledge at multiple scales about coupled human and natural systems. One approach has been to determine variation of both vegetation structure among urban neighborhoods, and community level motivations and capacity for vegetation management (Grove et al. 2006a). A study found that lifestyle traits associated with group identity and social status, as well as the housing structure of neighborhoods, were related to patterns of vegetation on private urban lands (Troy et al. 2007). A similar study found that a lifestyle behavior classification was the best predictor of distribution of vegetation cover on private lands, suggesting that urban vegetation management can be improved by developing marketing strategies that address household attributes beyond simple demographics such as education and income (Grove et al. 2006b).

Other studies address multiple characteristics of residential places and have found that trees and open space are often favored. Fried (1984) compared an exhaustive list of residential and neighborhood attributes and found that access to nature (expressed as the immediate outdoors, and closeness of large open spaces) was an important contributor to community satisfaction. Studies by Kaplan and colleagues have shown greater neighborhood satisfaction when residents can experience more natural rather than built settings, and satisfaction was far greater when residents could see even a few trees than when their view was of large open spaces (Kaplan 1985). Having natural elements or settings in the window view from homes contributes substantially to residents' satisfactions with their neighborhood and sense of well-being (Kaplan 2001). Considering a range of physical elements as contributors to neighborhood satisfaction, trees have a positive effect (Kweon et al. 2010). Specifically, the availability of forests and other trees, well-landscaped grounds, and places for taking walks are appreciated (Kaplan and Austin 2004). Loss can bring clarity to what is valued; following a major hurricane, more than $30 \%$ of residents of Charleston, South Carolina, U.S., identified urban trees as being the most significant feature of the city that was damaged (Hull 1992).

There are potential urban forestry conflicts embedded within neighborhood social interactions. One example is the emerging issue of tree shade and solar panels. Strategic planting of shade trees, particularly on southwest building exposures and near air conditioning units, can reduce residential energy use (McPherson et al. 2007). Yet tree placement for shade and reduced energy use may reduce solar panel effectiveness, another energy savings strategy, leading to tree versus solar panel conflicts (Anders et. al 2010; Baker 2010). Controversial litigation and public demands in response to the California Solar Shade Act (1978) led to later passage of a state bill that protects trees planted prior to the installation of neighboring solar panels (Barringer 2008a; Barringer 2008b). This is but one example of the complex balancing act between urban forest canopy goals and other beneficial uses and property improvements found within urban neighborhoods.

\section{Research Framework}

Canopy cover targets are urban planning goals that intersect with other urban initiatives. The successful implementation of these initiatives demands attention to social systems ranging in scale from citywide policy setting to property owner action. Lands in private ownership represent a large proportion of existing and potential canopy area, thus a better understanding of landowners' attitudes and behaviors concerning trees is important. Prior studies have addressed the role of nature and open space in community and neighborhood level satisfaction. More detailed studies have assessed public response to street trees, yet right-of-way planting may provide limited planting area relative to adjacent residential parcels. Most 
prior studies have addressed perceptions and attitudes such as tree preference and satisfaction; few have addressed behavior history or intention. This study was designed to address both attitudinal and behavioral patterns of single-family homeowners concerning all trees that they may plant or manage. This study differs from past studies in that results are analyzed and presented in association with neighborhood units deemed to be important for later tree program development and delivery. The research was guided by the following questions:

1. What are urban homeowners' past and future tree planting and care behavior patterns?

2. Are there variations in perceptions, attitudes, and behavior patterns by geographic district?

\section{METHODS}

Fifty-six percent of the land in Seattle is composed of singlefamily parcels. Municipal officials were interested in the tree planting patterns, attitudes, and behaviors of owners of private property. To address the research questions, a webbased survey was developed and implemented for singlefamily homeowners across the city. Analysis addressed citywide response as well as results at the neighborhood scale.

\section{The Residential Trees Survey}

The survey was constructed based on several sources. Earlier published tree surveys were reviewed, as was conceptual literature on the importance of recognizing the benefits and barriers to target audiences when attempting to change behaviors that impact the environment (McKenzie-Mohr 2011). Formative interviews were held with four homeowners and five local urban forestry professionals in the arboriculture, design, nonprofit, and policy fields. These resources were used to construct the Residential Trees Survey following commonly accepted survey methodology (Salant and Dillman 1994; Dillman et al. 2009). The final Residential Trees Survey consisted of three parts: 1) respondent agreement with various benefits and barriers to trees on a Likert scale of 1 (strongly disagree) to 5 (strongly agree); 2) ratings and reports of tree planting and retention behavior, such as pruning habits, number of trees planted and removed in the past, and type of tree likely to plant in the future; and 3) respondent demographics.

\section{Respondent Sampling}

Survey recruitment letters were sent to single-family homeowners (renters excluded), with contact information taken from King County tax records. Starting with a sample frame of all homeowners, sampling was first stratified by neighborhood using the 53 Community Reporting Areas (CRAs) that are used by the City of Seattle for internal reporting. Note that in this research, the terms CRA and neighborhood are used interchangeably. The final sample of participants was randomly selected from within the CRA stratification based on population distribution. Due to issues of self-locating by respondents versus administrative neighborhood designations, results were aggregated to the District level, judged to be a more accurate geographic representation. Each District (there are thirteen across the city) is composed of between three to five CRAs.

\section{Respondent Recruitment and Response}

The Tailored Design Method (Dillman et al. 2009) guided the process of respondent contact and recruitment. A prenotice postcard was sent four days prior to sending a letter inviting residents to participate in the online survey. Invitation letters were personalized with the homeowner's name as it appears on tax records. All letters were hand-signed. One week after letter mailings, participants received a reminder postcard, again including the link to the survey. All mailings were sent with first class stamps, rather than bulk mail.

A response incentive was included in the invitation letter, a coupon for a free bowl of clam chowder at a local restaurant. Coincidentally, invitation letters with coupons were delivered at the same time that the restaurant was prominent in local news headlines due to a unique marketing campaign (Lacitis 2009). Increased public attention to the restaurant may have helped capture participants' attention and increase return rates.

Of the 2,485 participation invitations sent, 91 were returned by the post office as undeliverable, reducing the sample size to 2,394. From this adjusted total, 751 surveys were completed, resulting in a $31 \%$ response rate. Response rates varied by CRA and district. The highest district response rate $(41 \%)$ was in District 6 (Central Seattle, including the neighborhoods of Capitol Hill, First Hill, Madison Park, Miller Park, and North Capitol Hill). The lowest response rate $(15 \%)$ was in District 3 (Southeast Seattle, including the neighborhoods of Beacon Hill, Duwamish, Georgetown, North Beacon Hill/Jefferson Park, South Beacon Hill/New Holly, and South Park).

\section{Citywide Respondent Demographics}

Mean age of respondents was 51 (standard deviation [sd] 12.6). The average number of years respondents had lived in their current home was 14.6 (sd 11.9), and expected continued occupancy was 16.3 (sd 15.9). Mean household occupancy was 2.6 persons (sd 1.1). Forty-two percent of respondents reported owning an average-sized parcel $\left(464.5 \mathrm{~m}^{2}\right.$ in Seattle), with $21 \%$ having smaller and $30 \%$ reporting larger parcels. Respondents were well-educated, with $38 \%$ having a college degree and $44 \%$ having a graduate or professional degree. Education levels were reflected in household income: $26 \%$ had income below $\$ 75,000,50 \%$ spanned $\$ 75,000$ up to $\$ 150,000$, and $24 \%$ had household incomes greater than $\$ 150,000$. Eighty-eight percent of respondents were white, while Asian $(5 \%)$ and biracial or mixed race $(3 \%)$ were the next highest cultural response categories. The overall demographics of the Residential Trees Survey reflect the demographics of all Seattle homeowners, as reported in the U.S. Census Bureau's American Community Survey (Table 1). This observed alignment does not rule out nonresponse bias (addressed in the discussion section), but did suggest that responses correlate to the intended human population. In addition, survey analysis did not include comparison of demographics between neighborhoods. This is also addressed in the discussion.

\section{RESULTS ACROSS SINGLE-FAMILY HOMEOWNERS}

Survey responses were first analyzed to explore planting and pruning behaviors of single-family homeowners across the city. Results revealed how homeowners inter- 
Table 1. Demographic comparison of survey respondents and U.S. census data for study area (2006-2008 American Community Survey, U.S. Census Bureau).

\begin{tabular}{lll}
\hline & Homeowner land-use survey & American community survey \\
\hline Population surveyed & Seattle single-family residential homeowners & All homeowners in Seattle (single family and multi-family) \\
Race & $88.2 \%$ white & $81.7 \%$ white \\
Age & mean $=51$ years & Most common age bracket $(24.8 \%)$ is $45-54$ \\
Education & $38 \%$ bachelors degree & $66.7 \%$ have bachelors degree or higher \\
& $43.9 \%$ graduate or professional degree & \\
Residency & Average time lived in current home & \\
& $=14.6$ years & $45.7 \%$ moved into their home in 2000 or later \\
\hline
\end{tabular}

acted with trees on their property over their term of ownership, in terms of both planting and pruning behaviors. This empirical information can enable urban forest managers to more effectively reach out and provide management guidance and support to a key land-use population.

\section{Planting Behavior}

With regard to when people plant trees, $48 \%$ of survey respondents reported that their most recent tree planting occurred in the spring. Thirty-six percent last planted in autumn, $13 \%$ planted in the summer, and $3 \%$ planted in winter.

When asked what type of tree they last planted and what type of tree they would likely plant in the future, respondents showed a clear preference for small ornamental trees and tendency away from large evergreens. Respondents planted far greater numbers of small deciduous/ornamental trees than evergreen trees (Figure 1). Fruit trees are more popular than they were in the past, as $42.4 \%$ of respondents intended to plant a fruit tree in the future, compared to $19 \%$ who have planted one in the past. The survey also asked respondents about the circumstances surrounding their most recent tree planting. The most common events that motivated plantings (Figure 2) were planting a tree as part of a larger landscaping project $(24.8 \%$ of respondents), or to replace an existing tree (17.2\%).

Homeowners were asked if preserving sunlight for future solar panel installation influences current decisions about trees; $7.5 \%$ of survey respondents answered "yes." Nineteen percent of survey respondents stated that they either currently have air conditioning units or are considering adding them to their homes in the next 5-10 years.

Homeowners report that they will plant fewer trees in the future than they have in the past. On average, respondents planted 3.4 trees per household in the past, but are considering planting 2.1 trees per household in the future.

\section{Pruning Behavior}

Eighty-eight percent of respondents reported having pruned a tree in their yard. Of those who pruned a tree, $60 \%$ reported that they did the work themselves, $28 \%$ hired a certified arborist, and $10 \%$ hired an uncertified person. In terms of motivation for pruning, $64.2 \%$ of respondents who had pruned a tree did so to improve the tree's shape, $59 \%$ to remove dead or damaged wood, $23.4 \%$ to provide clearance for utility lines, $22.1 \%$ to increase sunlight, $19 \%$ to increase fruit production, and $13 \%$ to create or improve a view.

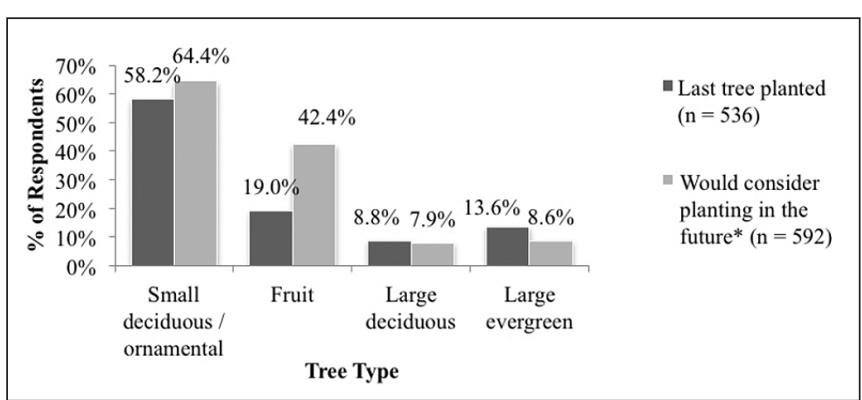

Figure 1. Comparison of past and future homeowner tree planting preferences. Note: multiple responses were possible.

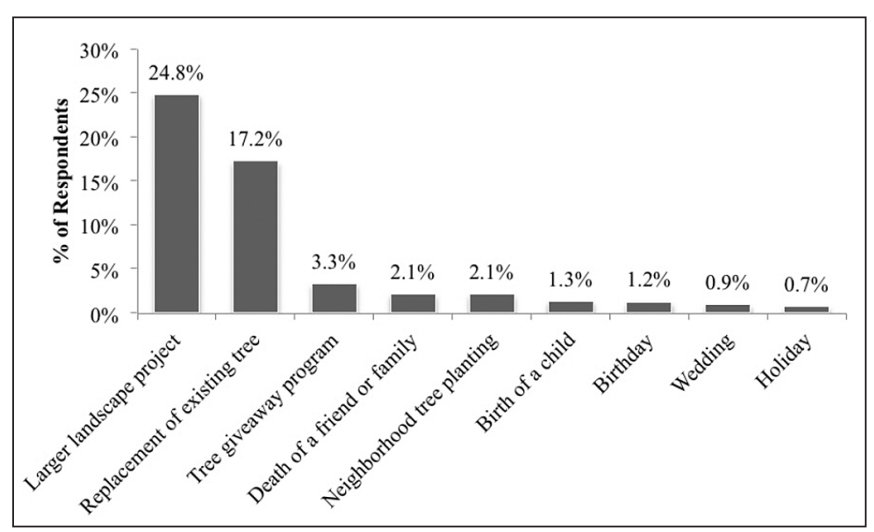

Figure 2. Homeowner motivations for past tree planting.

\section{RESPONSE ACROSS NEIGHBORHOOD DISTRICTS}

Data were also examined spatially to discern differences across the city's districts and to identify priorities for future resident outreach programs. Data from this research were analyzed in conjunction with canopy cover data from a 2009 City of Seattle study (based on 2007 remote sensing data). Canopy cover was estimated citywide, by land use or zoning classification, and within neighborhoods. These data indicated varied canopy density across the city (Parlin 2009). Further analysis nominated places with high planting potential. Results have enabled the City of Seattle to develop targeted canopy enhancement goals for tree planting within specific locations of the city.

In order to reach the City of Seattle's goal of 33\% canopy cover on single-family residential property, planting levels need to reach 6.4 net new trees per acre, not including planting to re- 
place removed trees. The survey indicated that no district in the city is currently being reforested at this planting rate. Survey data were used to spatially align current canopy cover, planting potential, and reported future planting behaviors by district (Figure $3)$. Respondents in the West Seattle district expected to plant the greatest number of trees in the future (5.4 trees/acre on average) while respondents in Duwamish district expected to plant the fewest number of trees in the future (2.4 trees/acre on average).

Responses to the attitude question, "Trees must be planted and selected properly and I don't know how" were also examined geographically. Positive responses ("agree" and "strongly agree") were mapped by district (Figure 4) to visually correlate with 2009 canopy cover and planting potential analysis. The district where the most respondents (32\%) reported a lack of planting and selection knowledge was the area just west of the Duwamish River (in south Seattle). The lowest reported rate of planting and selection knowledge $(8 \%)$ was in the Wallingford/Fremont district of north Seattle. Areas of relatively low canopy cover and relatively high planting potential were of particular interest for the analysis.

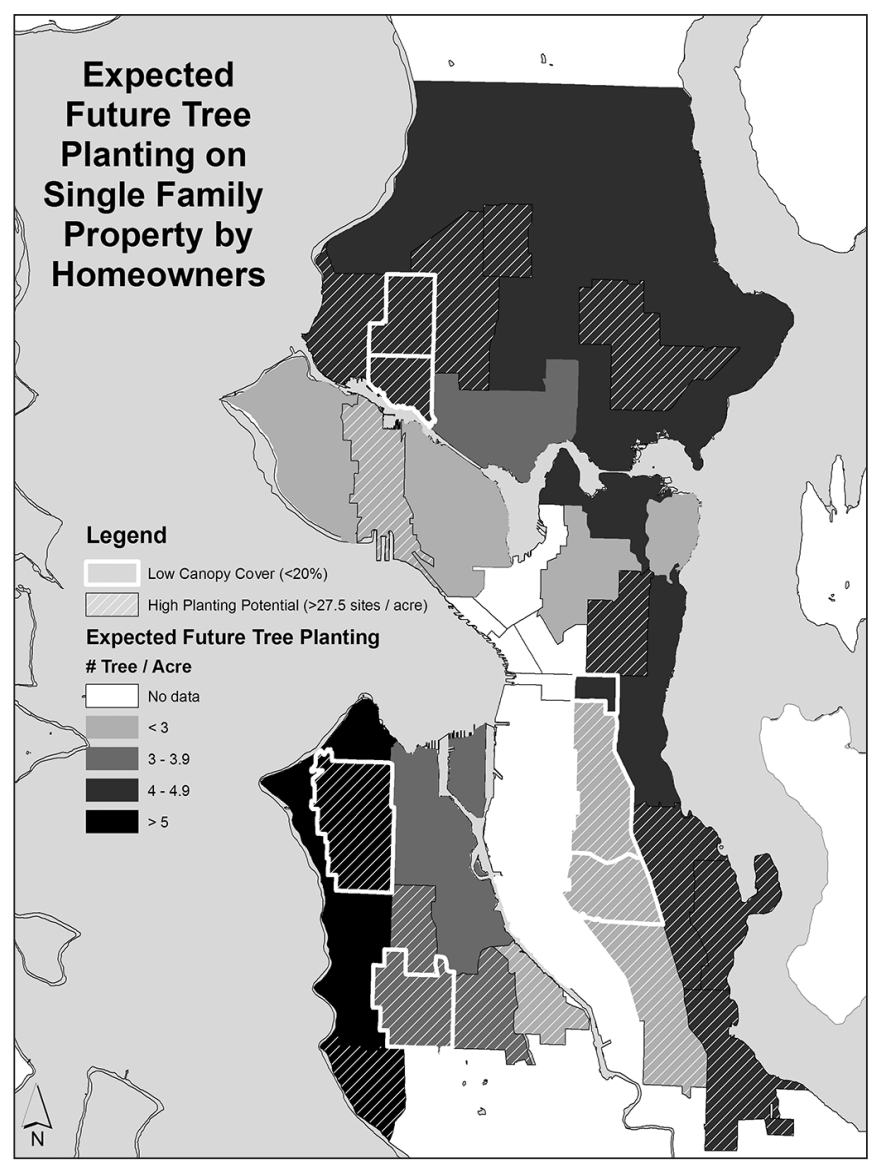

Figure 3. Geographic distribution of homeowners' expected future tree planting. Expected future tree planting is represented by the average number of future trees per acre on single-family residential property across the city, calculated as the number of trees respondents reported to be considering planting in the future on average by district, times the number of single family parcels in each district, divided by the number of acres in each district.

\section{DISCUSSION}

This research addressed homeowner attitudes and behaviors in an effort to increase tree planting and retention across an entire urban area and boost canopy cover (and resulting benefits). Findings highlight the human dimension issues that urban forest managers should consider when working to increase tree planting on single-family residential property, and suggest additional questions for future research. Findings of the current research on tree planting behavior are now informing the City's delivery of tree programs and homeowner outreach.

\section{Tree Planting Behaviors}

Planting levels in Seattle may be slowing on single-family properties. It is unknown whether this is an isolated pattern, or consistent with other cities in the country. Regardless, Seattle's urban forest managers are now aware that within limitations of self-reported predictions of future behavior, single-family residence canopy cover could decline without interventions, such as regulations, planting, or incentive programs. It is possible that residents will plant more (or fewer) trees in the future than they believed they would at the time of the survey.

Climate patterns differ across cities, affecting recommended planting seasons. Trees planted in autumn or winter have more time to establish root systems and survive the warm, dry summers typical of the coastal Pacific Northwest region of the United States. Trees planted in the spring or summer are less likely to survive and thrive into maturity. The majority of Seattle's homeowners are not planting at the recommended time. This may be partly due to local nursery practices that promote tree sales in the spring. In Seattle, and elsewhere, urban forest managers may need to encourage the retail nursery industry and homeowners to shift planting behavior to the most appropriate season.

Respondents indicated a "downsizing" trend in species preference. Yet large trees provide greater environmental, social, and economic benefits than do small trees (McPherson et al. 2002; Wolf 2005; Sydnor and Subburayalu 2011). Evergreen trees, such as the large coniferous trees native in the Pacific Northwest, can intercept greater amounts of rainwater than deciduous trees (Xiao et al. 1998; Xiao et al. 2000; Link et al. 2004; Xiao and McPherson 2011), thus providing greater stormwater management benefits. However, suitable public planting locations for large trees are becoming less available in densely developed areas. Thus, working with homeowners through incentive programs or technical assistance to plant such trees on private property (e.g., in yards) may be one of the best ways to increase the number of large trees in urban areas.

\section{Solar Panels and Energy Demand}

Less than $10 \%$ of respondents indicated that their tree planting decisions were influenced by the desire to maintain solar access for future panel installations. This attitude may be more common in southern, sunnier cities. A more direct issue in the Seattle climate may be energy demand.

There are a number of ways to reduce residential energy use, including less use of air conditioning. Seattle has mild summers, and few residents use home air conditioning. However, in 2009 Seattle experienced record-breaking summer heat, with temperatures exceeding the previous high of $39.4^{\circ} \mathrm{C}$ (Mass 2009). If such heat trends continue, more residents may 
install air conditioning units. Also, $19.1 \%$ of survey respondents reported either currently have air conditioning units or were considering installing them within the next 5 to 10 years.

Not only can urban trees shade homes directly, but they can also reduce heat island effects by reducing the temperature of an entire urban area (McPherson et al. 2007). Increased planting of shade trees may reduce future air conditioning unit installations and the associated increased residential energy use. Cooling shade on a single property and across the city may also influence homeowner decisions about meeting energy needs with solar panel installations. Research about urban forest environmental benefits has typically investigated one benefit or positive co-benefits; investigations about energy benefits tradeoffs is a social science opportunity.

\section{Fruit Tree Trends}

Public programs that promote a civic need may connect residents to related issues of tree benefits and tree care; an example is food security. There is growing interest in fruit trees in Seattle, with $19 \%$ of surveyed homeowners having planted a fruit tree in the past, to $42 \%$ who say they will do so in the future. Reported attitudes may be due to general public discourse about urban agriculture, food security, and local food production, as well as the City of Seattle's declaration of 2010 as the Year of Urban Agriculture (City of Seattle 2010). Fruit trees, though lesser contributors to canopy cover than shade trees given their typically smaller size, could be an entry point to interest homeowners in urban forestry and additional tree planting. Public communications about fruit trees should address their possible downsides, such as the production of more fruit than can be consumed by a household, as well as rats and other pests that are attracted to fallen fruit, and the possible increase in the use of chemicals to treat pests and diseases. A policy concern is that homeowner choice to remove large, mature trees to create more sunlight for small, deciduous trees could be counter-productive for canopy cover goals, offering another benefits tradeoff research opportunity.

\section{Tree Pruning}

Correct pruning practices contribute to better tree health and vitality, helping to reduce property damage and safety hazards (Gilman 2011). Homeowners are often pruning trees themselves, rather than hiring trained professionals; $88 \%$ of survey respondents reported having pruned a tree in their yard [similar to the $85 \%$ rate found by Summit and McPherson (1998)]. Urban forest managers can develop and circulate pruning information, such as brochures and online postings, but other more direct approaches, such as workshops with demonstrations of proper pruning techniques, may be more effective (Close et al. 2001).

Ten percent of survey participants reported hiring an uncertified tree worker to prune trees. Pruning work conducted by unqualified persons may be more likely to include arboricultural practices that are detrimental, such as topping. The importance of the professional expertise provided by certified, insured arborists is another public outreach opportunity.

\section{Geographic Distributions}

Canopy level assessments across a city generate baseline data, and are often used to inform goals and policy. Better under- standing of the resource helps mobilize support for tree planting (such as the Million Tree campaigns of New York City, New York; Los Angeles, California; or Baltimore, Maryland, U.S.) and tree conservation. In addition, better knowledge about geographic variations in homeowner behavior and attitudes can help urban forest managers deliver programs to targeted areas, thus using limited budgets and other resources more effectively.

Sufficient data were not available in this study to analyze response influences at the parcel or household scale; variability could be due to factors such as yard size, existing canopy cover within and in proximity to lots, and age of neighborhood. Nonetheless, combining canopy cover and planting potential data with respondent attitude data can guide more strategic service delivery at the district or neighborhood level. For example, a neighborhood where residents report being less likely to plant trees in the future compared to other neighborhoods might be judged a high priority for planting outreach to change attitudes. However, if reported attitudes are considered in conjunction with canopy cover and planting potential data, it may be that an existing abundance of trees contributes to residents' reluctance to plant more. Figure 4 reveals neighborhoods where perceived knowledge of trees, expected future planting, and canopy cover are all low, and planting potential is high. These may be the regions where tree planting outreach and programs will have the greatest impact.

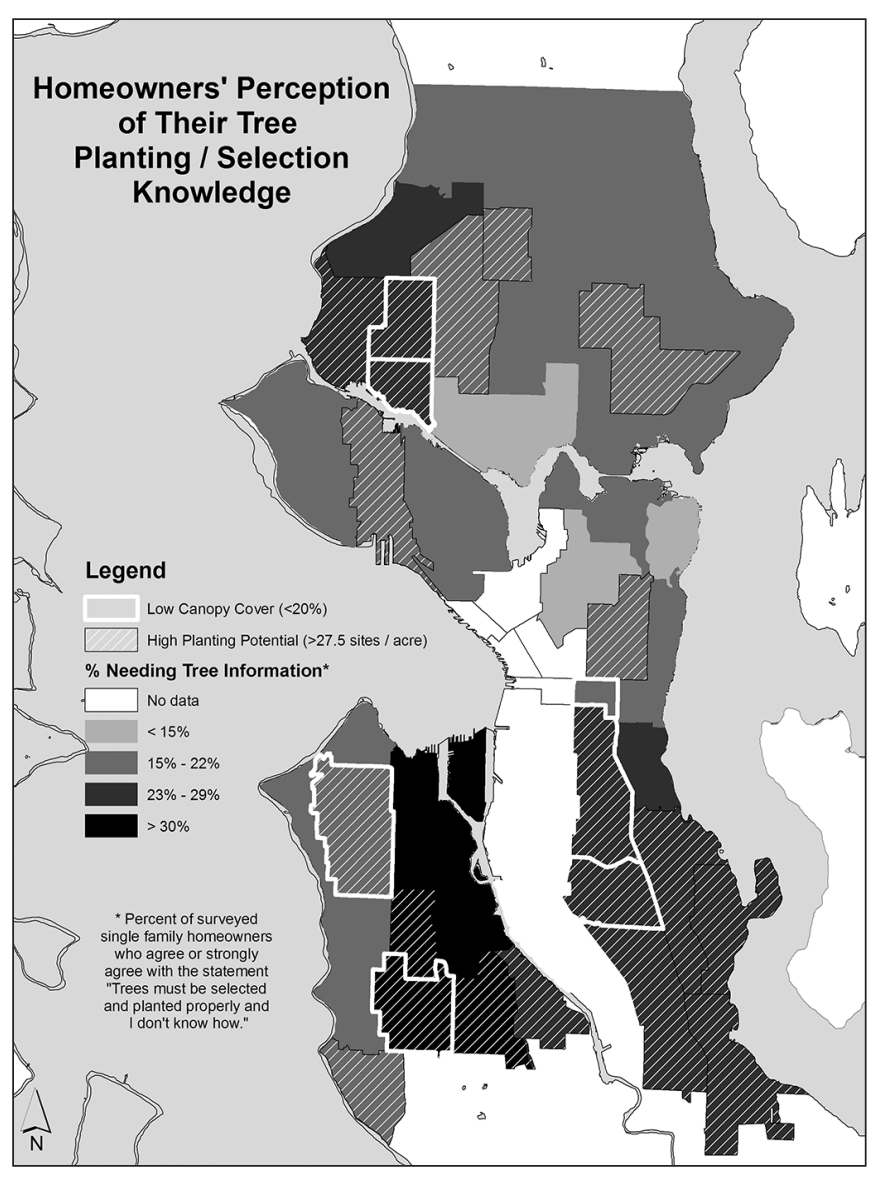

Figure 4. Survey respondents' perceptions of their tree selection and planting knowledge. 


\section{Limitations}

There are limitations associated with survey research that may have affected this study. Non-response bias complicates the process of making inferences about populations at the neighborhood, district, or city scale. Non-response factors may have included lack of internet access or language barriers within recruited households (Dillman et al. 2009), particularly in districts that have a more diverse cultural composition or lower median household income. Analysis did not assess whether neighborhood response represented local demographics, thus the comparability of cultural or socioeconomic diversity within neighborhood responses is unknown. Also, there was a variable rate of undeliverable recruitment letters across neighborhoods. There were also variable rates of response to successful recruitments, with higher rates associated with more affluent districts of the city. In addition, a possible response influence is that people feeling both a workfamily conflict and time pressure are more likely non-respondents (Vercruyssen et al. 2011), and may be the people who are less active in planning or maintaining their personal landscape.

Given the City of Seattle's dedication to residential tree planting, the decision was made to invest up front in high quality survey outreach. The tailored, multi-contact approach was used as it has been shown to generate higher response rates (Dillman et al. 2009). The use of incentives has a long history in mail surveys (Singer 2002), and a meta-analysis of survey studies found that prepaid incentives that are delivered with the survey (as was done in this study) yield significantly higher response rates whereas contingent (promised) incentives do not (Church 1993). Despite these efforts, a moderately acceptable response rate was achieved. Non-response bias could be addressed post hoc (as summarized by Groves 2006) by 1) comparing initial and late respondents, as late returns may be similar to non-responders; 2) comparing survey results to known population parameters, which was done on a very general demographical level; 3) contacting and surveying a sample of nonrespondents after the survey was completed; and 4) inspecting variables known to indicate bias. Due to the City of Seattle's satisfaction with the final response rate, not all of these post hoc comparisons were done.

\section{Future Research}

Many studies have assessed public perceptions, preferences, and satisfaction for trees in cities and within residential settings. This research differs in that it was one of the few studies to assess how homeowners interact with the trees in their yard, thereby influencing the canopy cover and associated benefits of urban forests. Additional studies could further assist urban forest managers in developing effective tools to communicate with and engage urban residents in tree planting and care. Similar research could be done in other cities to compare homeowner attitudes and behaviors on a national scale and identify geographic patterns of behavior in other areas. Of particular interest are the situations of where a choice must be made between two conflicting sets of benefits, such as the choice between shade trees and solar panels or planting small versus large trees. Additional research themes follow.

\section{Attitudes and behavior of other private property owners}

This research focused solely on single-family homeowners. Additional research could examine the behaviors and attitudes of renters, rental property owners and landlords, multi-family homeown- ers, and commercial property owners toward trees. These groups may act in significantly different ways than single-family homeowners, meaning that urban forest managers may need to construct different programs to address canopy cover across such properties.

\section{Improved survey response rates}

Declining response rates are an ongoing concern in survey research. The Pew Center for Research found that from the 1990s to the 2000s the household response rate to standard surveys declined from $36 \%$ to $27 \%$ (Kohut et al. 2004). One firm's meta-analysis of 199 general population surveys indicated a median survey response rate of $26 \%$ (Hamilton 2009). Kaplowitz et al. (2004) tested five questionnaire distribution treatments using combinations of mail and e-mail contact, finding that response rates ranged from $21 \%$ to $32 \%$. This project's response rate compares favorably to trends in general population surveys, but a higher rate would generate more confidence in results as the basis of city programs.

If future surveys of homeowners or other property owners are to be done, then new tactics should be attempted and evaluated for more effective data collection. Strategies to boost response could include developing a survey that is shorter in length (Edwards et al. 2002), and has higher topic interest (Martin 1994) or involvement (Van Kenhove et al. 2002). Vegetation mapping could be used to tailor the study region and sample design to focus outreach effort on specific districts of interest, rather than sampling the entire city, and would allow survey resources to be directed into higher response approaches, such as telephone, door-to-door interview, or drop-off and pick-up surveys.

\section{Barriers to large tree planting}

Further research could be conducted on how to encourage the planting of tree species that generate the greatest environmental benefits, particularly large evergreens. Managers would benefit from a better understanding of the behavioral barriers that discourage large tree planting by homeowners in order to design specific outreach programs. Possible barriers to large tree planting identified in pre-survey interviews included perceived tree failure risk, perceived legal liability, limited capacity for households to take on large tree management tasks, and space constraints.

\section{CONCLUSIONS}

Urban forest planning and management involves complex human dimensions of attitudes, perceptions, and behavior. As urban forest managers work to build sustainable urban forests, it can be helpful to understand the ways in which the public, and in particular homeowners, interact with and influence urban greenery. Social scientists can contribute to understanding the social and community diversity embedded within resource systems. This study, for instance, pursued data that could be used to understand homeowner tree practices (such as large tree and season choice for planting) and reconcile them with the public appreciations for trees found in the literature review, as attitude and action are not always consistent (do Paço and Raposo 2009).

Scale plays a role in both data collection and resource management. Not all cities use neighborhoods as the administrative unit of planning or program delivery, but urban forest managers can designate units within their cities to help organize and prioritize urban forest activity. Some cities have discovered that trees and parks have not been equitably provided to all of their communi- 
ties; a management by unit approach could acknowledge this possibility, and perhaps serve to correct disparate canopy distribution.

At the parcel scale, homeowners have varied motives and commitment concerning tree planting and management. Knowing about general patterns of attitudes and behavior can help urban forest managers to reach specific audiences, similar to methods of marketing segmentation (Wedel and Kamakura 2000). Programs of public planting along streets, combined with targeted planting support for adjacent homeowners could lead to visible 'hot spots' of canopy development that boost residential canopy rates, attract broader public support, and improve the sustainability of urban forests.

Acknowledgments. Funding for this research was provided by the City of Seattle, Office of Sustainability and Environment; the Garden Club of America; Ivar's Seafood Restaurants; and the USDA Forest Service, Urban and Community Forestry Program. The authors appreciate the contributions of Drs. Gordon Bradley and Anne Bostrom (University of Washington) to this research.

\section{LITERATURE CITED}

Anders, S., T. Day, and C.A. Kuduk. 2010. Hey, your tree is shading my solar panels: California's Solar Shade Control Act. Journal of Sustainable Real Estate 2:361-381.

Baker, R.L. 2010. My tree versus your solar collector or your well versus my septic system? Exploring responses to beneficial but conflicting neighboring uses of land. Boston College Environmental Affairs Law Review 37(1):Article 2.

Barringer, F. April 7, 2008a. Trees block solar panels, and a feud ends in court. The New York Times. <www.nytimes.com/2008/04/07/ science/earth/07redwood.html?scp=1\&sq=trees $\% 20$ block $\% 20$ solar\%20panels\&st=cse>

Barringer, F. July 23, 2008b. In California neighbors' dispute, officials find it's time to speak for the trees. The New York Times. <www. nytimes.com/2008/07/23/us/23solar.html? scp=4\&sq=trees $\% 20$ block\%20solar\%20panels\&st=cse>

Cadenasso, M.L., S.T.A. Pickett, and K. Schwarz. 2007. Spatial heterogeneity in urban ecosystems: Reconceptualizing land cover and a framework for classification. Frontiers in Ecology and the Environment 5(2):80-88.

Chaskin, J. 1998. Neighborhood as a unit of planning and action: A heuristic approach. Journal of Planning Literature 13(1):11-30.

Church, A.H. 1993. Estimating the effect of incentives on mail survey response rates: A meta-analysis. Public Opinion Quarterly 57:62-79.

City of Seattle. 2007. Urban Forest Management Plan. <www.seattle. gov/trees/management.htm>

City of Seattle. 2010. 2010: The Year of Urban Agriculture: Promoting community agriculture efforts and increased access to locally grown food. <www.seattle.gov/urbanagriculture>

City of Seattle. 2013. Michael McGinn. Executive Order 2013-01.

Clark, J.R., N.P. Matheny, G. Cross, and V. Wake. 1997. A model of urban forest sustainability. Journal of Arboriculture 23(1):17-30.

Close, D.D., J.W. Groninger, J.C. Mangun, and P.L. Roth. 2001. Homeowners' opinions on the practice and effects of topping trees. Journal of Arboriculture 27(3):160-65.

Davey Resource Group. 2012. Pittsburgh Urban Forest Master Plan. $<$ www.treepittsburgh.org/urban-forest-master-plan>

Decker, D.J., T.L. Brown, and W.F. Siemer. 2001. Evolution of peoplewildlife relations. pp. 3-22. In: D.J. Decker, T.L. Brown, and W.F.
Siemer (Eds.). Human Dimensions of Wildlife Management in North America. The Wildlife Society, Bethesda, Maryland.

Dillman, D.A., J.D. Smyth, and L.M. Christian. 2009. Internet, Mail and Mixed-Mode Surveys. John Wiley \& Sons, Hoboken, New Jersey, U.S. 499 pp.

Donovan, G.H., and D.T. Butry. 2010. Trees in the city: Valuing street trees in Portland, Oregon. Landscape and Urban Planning 94:77-83.

Donovan, G.H., and D.T. Butry. 2011. The Effect of urban trees on the rental price of single-family homes in Portland, Oregon. Urban Forestry \& Urban Greening 10:163-68.

Donovan, G.H., D.T. Butry, Y.L. Michael, J.P. Prestemon, A.M. Liebhold, D. Gatziolis, and M.Y. Mao. 2013. The relationship between trees and human health: Evidence from the spread of the emerald ash borer. American Journal of Preventive Medicine 44(2):139-145.

Donovan, G.H., Y.L. Michael, D.T. Butry, A.D. Sullivan, and J.M. Chase. 2011. Urban trees and the risk of poor birth outcomes. Health \& Place 17(1):390-93.

Donovan, G.H., and J.P. Prestemon. 2012. The Effect of Trees on Crime in Portland, Oregon. Environment and Behavior 44(1):3-30.

do Paço, A., and M. Raposo. 2009. Green segmentation: An application to the Portuguese consumer market. Marketing Intelligence \& Planning 27(3):364-379.

Dwyer, J.F., D.J. Nowak, and M.H. Noble. 2003. Sustaining urban forests. Journal of Arboriculture 29(1):49-55.

Dwyer, J.F., D.J. Nowak, M.H. Noble, and S.M. Sisinni. 2000. Connecting People with ecosystems in the 21st Century: An Assessment of Our Nation's Urban Forests. Gen. Tech. Rep. PNW-GTR-490. Portland, OR: U.S. Department of Agriculture, Forest Service, Pacific Northwest Research Station.

Edwards, P., I. Roberts, M. Clarke, C. DiGuiseppi, S. Pratap, R. Wentz, and I. Kwan. 2002. Increasing response rates to postal questionnaires: Systematic review. BMJ 324(7347):1183-1185.

Flannigan, J. 2005. An evaluation of residents' attitudes to street trees in southwest England. Arboricultural Journal 28(4):219-241.

Flint, C.G., B. McFarlane, and M. Müller. 2009. Human dimensions of forest disturbance by insects: An international synthesis. Environmental Management 43(6):1174-186.

Fried, M. 1984. The structure and significance of community satisfaction. Population \& Environment 7(2):61-86.

Gilman, E.F. 2011. An Illustrated Guide to Pruning, 3rd Edition. Delmar, Clifton Park, New York, New York, U.S. 496 pp.

Gorman, J. 2004. Residents' opinions on the value of street trees depending on tree allocation. Journal of Arboriculture 30(1):36-43.

Grove, J.M., M.L. Cadenasso, W.R. Burch, Jr., S.T.A. Pickett, K. Schwarz, J. O'Neil-Dunne, M. Wilson, A. Troy, and C. Boone. 2006a. Data and methods comparing social structure and vegetation structure of urban neighborhoods in Baltimore, Maryland. Society and Natural Resources 19(2):117-136.

Grove, J.M., A.R. Troy, J.P.M. O’Neil-Dunne, W.R. Burch, M.L. Cadenasso, and S.T.A. Pickett. 2006b. Characterization of households and its implications for the vegetation of urban ecosystems. Ecosystems 9(4):578-597.

Groves, R.M. 2006. Nonresponse rates and nonresponse bias in household surveys. Public Opinion Quarterly 70(5):646-675.

Hamilton, M.B. 2009. Online Survey Response Rates and Times: Background and Guidance for Industry. Super Survey: A Solution from Ipathia, Inc.

Heimlich, J., T.D. Sydnor, M. Bumgardner, and P. O'Brien. 2008. Attitudes of residents toward street trees on four streets in Toledo, Ohio, 
US before removal of ash trees (Fraxinus spp.) from emerald ash borer (Agrilus planipennis). Arboriculture \& Urban Forestry 34(1):47-53.

Hull, R.B. 1992. How the public values urban forests. Journal of Arboriculture 18(2):98-101.

Jorgensen, E. 1974. Towards an urban forestry concept. Prepared for the 10th Commonwealth Forestry Conference, Ottawa, Canada.

Kaplan, R. 1985. Nature at the doorstep: Residential satisfaction and the nearby environment. Journal of Architectural and Planning Research 2:115-127.

Kaplan, R. 2001. The nature of the view from home: Psychological benefits. Environment and Behavior 33(4):507-542.

Kaplan, R., and M. Austin. 2004. Out in the country: Sprawl and the quest for nature nearby. Landscape and Urban Planning 69:235-243.

Kaplowitz, M.D., T.D. Hadlock, and R. Levine. 2004. A comparison of web and mail survey response rates. Public Opinion Quarterly 68(1):94-101.

Kenney, W.A., P.J.E. van Wassenaer, and A.L. Satel. 2011. Criteria and indicators for strategic urban forest planning and management. Arboriculture \& Urban Forestry 37(3):108-117.

Kohut, A., C. Doherty, and S. Keeter. 2004. Polls Face Growing Resistance, But Still Representative. Pew Center for Research on People and the Press, Washington, D.C. 37 pp.

Kweon, B.S., C. Ellis, P.I. Leiva, and G.O. Rogers. 2010. Landscape components, land use, and neighborhood satisfaction. Environment and Planning B: Planning and Design 37:500-517.

Lacitis, E. September 18, 2009. Is there something fishy about Ivar's latest stunt? Seattle Times. <www.seattletimes.nwsource.com/html/ localnews/2009889864_ivar18m.html>

Link, T.E., M. Unsworth, and D. Marks. 2004. The dynamics of rainfall interception by a seasonal temperate rainforest. Agricultural and Forest Meteorology 124(3-4):171-191.

Logan, J.R., and H.L. Molotch. 1987. Urban Fortunes: The Political Economy of Place. University of California Press, Berkeley, California, U.S.

Lohr, V.I., C.H. Pearson-Mims, J. Tarnai, and D. Dillman. 2004. How urban residents rate and rank the benefits and problems associated with trees in cities. Journal of Arboriculture 30(1):28-35.

Martin, C.L. 1994. The impact of topic interest on mail survey response behaviour. Journal of the Market Research Society 36(4):327-338.

Mass, C. July 29, 2009. One Record Down, One to Go? Update III. Cliff Mass Weather Blog. <www.cliffmass.blogspot.com/2009/07/updateiii.html>

McKenzie-Mohr, D. 2011. Fostering Sustainable Behavior: An Introduction to Community-Based Social Marketing, 3rd Edition. New Society Publishers, Gabriola Island, Canada. 192 pp.

McPherson, E.G., S.E. Maco, J.R. Simpson, P.J. Peper, Q. Xiao, A.M. VanDerZanden, and N. Bell. 2002. Western Washington and Oregon Community Tree Guide: Benefits, Costs, and Strategic Planting. International Society of Arboriculture, Pacific Northwest Chapter, Silverton, Oregon, U.S.

McPherson, E.G., J.R. Simpson, P.J. Peper, S.L. Gardner, K.E. Vargas, and Q. Xiao. 2007. Northeast Community Tree Guide: Benefits, Costs, and Strategic Planting. U.S.D.A. Forest Service General Technical Report PSW-GTR-202. U.S. Department of Agriculture, Forest Service, Pacific Southwest Research Station, Albany CA.

Nowak, D.J., S.M. Stein, et al. 2010. Sustaining America's Urban Trees and Forests: A Forests on the Edge Report. U.S.D.A. Forest Service General Technical Report NRS-62. U.S. Department of Agriculture, Forest Service, Northern Research Station.
Parlin, M. 2009. Seattle, Washington Urban Tree Canopy Analysis Project Report: Looking Back and Moving Forward. NCDC Imaging, Colorado Springs, Co. 15 pp.

Pickett, S.T., M.L. Cadenasso, J.M. Grove, C.G. Boone, P.M. Groffman, E. Irwin, S.S. Kaushal, V. Marshall, et al. 2011. Urban ecological systems: Scientific foundations and a decade of progress. Journal of Environmental Management 92(3):331-362.

Pickett, S.T.A., and M.L. Cadenasso. 2009. Altered resources, disturbance, and heterogeneity: A framework for comparing urban and non-urban soils. Urban Ecosystems 12(1):23-44.

RealtyTrac. March 2010. Seattle, WA Real Estate Trends. <www.realtytrac.com/trendcenter/wa/seattle-trend.html>

Rohe, W.M. 2009. From local to global: One hundred years of neighborhood planning. Journal of the American Planning Association 75(2):209-230.

Rosenfeld, A.H., H. Akbari, S. Bretz, and B.L. Fishman. 1995. Mitigation of urban heat islands: Materials, utility programs, updates. Energy and Buildings 22(3):255.

Salant, P., and D. Dillman. 1994. How to Conduct Your Own Survey. John Wiley \& Sons, New York. 232 pp.

Sander, H., S. Polasky, and R.G. Haight. 2010. The value of urban tree cover: A hedonic property price model in Ramsey and Dakota Counties, Minnesota, USA. Ecological Economics 69(8):1646-656.

Schroeder, H., J. Flannigan, and R. Coles. 2006. Residents' attitudes toward street trees in the UK and US communities. Arboriculture \& Urban Forestry 32(5):236-246.

Schroeder, H.W., and S.R. Ruffolo. 1996. Householder evaluations of street trees in a Chicago suburb. Journal of Arboriculture 22(1):35-43.

Seattle Department of Neighborhoods. 2012. Accessed 10/18/2012. $<$ www.seattle.gov/neighborhoodcouncil>

Silver, C. 1985. Neighborhood planning in historical perspective. Journal of the American Planning Association 51(2):161-174.

Singer, E. 2002. The Use of Incentives to Reduce Nonresponse in Household Surveys (No. 051). The University of Michigan Institute for Social Research Survey Research Center, Ann Arbor, Michigan, U.S. 34 pp.

Sirianni, C. 2007. Neighborhood planning as collaborative democratic design: The case of Seattle. Journal of the American Planning Association 73(4):373-387.

Sommer, R., P.A. Barker, H. Guenther, and K. Kurani. 1989. Householder evaluation of two street tree species. Journal of Arboriculture 15(4):99-103.

Sommer, R., and B.A. Sommer. 1989. The factor structure of street tree attributes. Journal of Arboriculture 15(10):243-246.

Sommer, R., H. Guenther, and P.A. Barker. 1990. Surveying householder response to street trees. Landscape Journal 9(2):79-85.

Summit, J., and E.G. McPherson. 1998. Residential tree planting and care: A study of attitudes and behavior in Sacramento, California. Journal of Arboriculture 24(2):89-96.

Sydnor, T.D., and S.K. Subburayalu. 2011. Should we consider expected environmental benefits when planting larger or smaller tree species? Arboriculture \& Urban Forestry 37(4):167-172.

Troy, A.R., J.M. Grove, J.P. O’Neil-Dunne, S.T. Pickett, and M.L. Cadenasso. 2007. Predicting opportunities for greening and patterns of vegetation on private urban lands. Environmental Management 40(3):394-412.

Van Kenhove, P., K. Wijnen, and K. De Wulf. 2002. The influence of topic involvement on mail-survey response behavior. Psychology and Marketing 19(3):293-301. 
Vercruyssen, A., H. Roose, and B.V. Putte. 2011. Underestimating busyness: Indications of nonresponse bias due to work-family conflict and time pressure. Social Science Research 40(6):1691-1701.

Wedel, M., and W.A. Kamakura. 2000. Market Segmentation: Conceptual and Methodological Foundations. Kluwer, Norwell, Massachusetts, U.S. 382 pp.

Wolf, K.L., and L.E. Kruger. 2010. Urban forestry research needs: A participatory assessment process. Journal of Forestry 108(1):39-44.

Wolf, K.L., D.J. Blahna, W. Brinkley, and M. Romolini. 2013. Environmental stewardship footprint research: Linking human agency and ecosystem health in the Puget Sound region. Urban Ecosystems 16:13-32.

Wolf, K.L. 2005. Business district streetscapes, trees, and consumer response. Journal of Forestry 103(8):396-400.

Xiao, Q., and E.G. McPherson. 2011. Rainfall interception of three trees in Oakland, California. Urban Ecosystems 14:755-769.

Xiao, Q., E.G. McPherson, J.R Simpson, and S.L. Ustin. 1998. Rainfall interception by Sacramento's urban forest. Journal of Arboriculture 24(4):235-244.

Xiao, Q., E.G. McPherson, S.L. Ustin, M.E. Grismer, and J.R. Simpson. 2000. Winter rainfall interception by two mature open-grown trees in Davis, California. Hydrological Processes 14:763-784.

Zhang, Y., A. Hussain, J. Deng, and N. Letson. 2007. Public attitudes toward urban trees and supporting urban tree programs. Environment and Behavior 39(6):797-814.

\section{Jana Dilley (corresponding author) \\ City of Seattle \\ jana.dilley@seattle.gov}

Kathleen L. Wolf, Ph.D.

University of Washington

School of Environmental and Forest Sciences

kwolf@uw.edu
Zusammenfassung. Urbane Wälder sind wegen ihrer vielen ökologischen, ökonomischen und sozialen Vorteile, die Stadtbäume liefern, kritische Elemente in nachhaltigen urbanen Arealen. Im Bemühen, die Kronenbedeckung in urbanen Räumen zu vergrößern, müssen sich $\mathrm{Gr}$ undstückseigentümer, die mehrheitlich das Land in den meisten Städten besitzen, bei der Pflanzung und Erhaltung von Bäumen auf ihren Grundstücken engagieren. Dieses gemeinschaftliche Forschungsprojekt befragte Hauseigentümer in Seattle, Washington, USA, zu ihrem Verhalten und ihrer Einstellung zu Bäumen auf ihren Grundstücken. Die Einstellungen zu Bäumen wurden auf Karten dargestellt, um die geographische Verteilung zu untersuchen, weil Seattle eine Altlast von auf Nachbarschaft basierter Planung besitzt. Die Ergebnisse zeigen, dass Hauseigentümer während ungünstiger Jahreszeiten Pflanzungen durchführten, dass sie kleinkronige Bäume bevorzugten und dass sie wachsendes Interesse an Obstbäumen haben. Hauseigentümer planen weniger Pflanzungen in der Zukunft, als sie in der Vergangenheit gepflanzt haben. Diese Forschung ist ein Modell für soziale Forschungsansätze, die verwendet werden können, um zielgerechte öffentliche Programme auf Nachbarschaftsebene zu entwickeln, die die Pflanzung und Erhaltung von Bäumen im Siedlungsbereich erhöhen.

Resumen. Los bosques urbanos son un elemento crítico en las zonas urbanas sostenibles debido a los muchos beneficios ambientales, económicos y sociales que proporcionan en la ciudad. Con el fin de aumentar la cobertura del dosel en las zonas urbanas, los propietarios de viviendas residenciales, que en conjunto poseen la mayor parte de los predios en la mayoría de las ciudades, necesitan participar en la plantación de árboles y su retención en sus propiedades. Este proyecto cooperativo de investigación encuestó a propietarios de viviendas en Seattle, Washington, EE.UU. para examinar sus comportamientos y actitudes hacia los árboles en su propiedad. Las actitudes hacia los árboles fueron asignadas al examinar la distribución geográfica, ya que Seattle tiene un legado de la planificación basada en el vecindario. Los resultados muestran que los propietarios plantan árboles en épocas no óptimas del año, los árboles preferidos son pequeños en la madurez sobre los árboles grandes y mostraron un mayor interés en los árboles frutales. Los propietarios tienen la intención de plantar menos árboles en el futuro de lo que lo han hecho en el pasado. Esta investigación es un modelo para los esfuerzos de la ciencia social que puede ser utilizado para desarrollar programas de divulgación dirigidos a escala de barrio con el fin de incrementar la plantación y mantenimiento de árboles en las viviendas. 